\title{
Phosphorylation of neuromodulin in rat striatum after acute and repeated, intermittent amphetamine
}

\author{
Margaret E. Gnegy, Patricia Hong and Sandra T Ferrell \\ Department of Pharmacology, Untversity of Michigan Medical School, Ann Arbor, MI 48109-0626 (USA)
}

(Accepted 27 April 1993)

Key words GAP 43, Calmodulın, Proteın kınase C, Post hoc phosphorylatıon assay, Sensıtızatıon, Synaptıc plastıcıty, Neural-specific protein, Synaptosome

\begin{abstract}
Repeated, intermittent treatment of rats with amphetamine results in a sensitization of locomotor and stereotyped behaviors that is accompanied by an enhancement in stımulus-ınduced dopamıne release Increased phosphorylation of the neural specitıc calmodulın-bındıng proteın, neuromodulin (GAP-43, B-50, F1) has been demonstrated in other forms of synaptic plasticity and plays a role in neurotransmitter release To determıne whether neuromodulin phosphorylatıon was altered durıng amphetamine sensitization, the in vivo phosphorylated state of neuromodulın was examıned in rat striatum in a post hoc phosphorylation assay Female, Holtzman rats received salıne or $25 \mathrm{mg} / \mathrm{kg}$ amphetamıne twice weekly for 5 weeks One week after the last dose of amphetamıne, rats were challenged with either $1 \mathrm{mg} / \mathrm{kg}$ or $25 \mathrm{mg} / \mathrm{kg}$ amphetamıne or salıne and the rats were sacrificed 30 min later Purified synaptic plasma membranes were prepared in the presence of EGTA and okadaic acid to inhibit dephosphorylation, and were subsequently phosphorylated in the presence of purified protein kınase C and $\left[\gamma-{ }^{32} \mathrm{P}\right] \mathrm{ATP}$ The proteın kınase C-mediated post hoc phosphorylation of neuromodulın was significantly reduced in groups that received either acute or repeated amphetamine suggestıng that neuromodulin in those groups contained more endogenous phosphate The acute, challenge dose of amphetamıne increased neuromodulin phosphorylation in the salıne-treated controls but not in the repeated amphetamine-pretreated group Antı-neuromodulin immunoblots showed no change in neuromodulın levels in any group There was no significant change in protein kinase $\mathrm{C}$ activity in any treatment group To further investigate the effect of acute amphetamine, the ability of amphetamine to alter neuromodulin phosphorylation in ${ }^{32} \mathrm{P}_{1}$-preincubated Percoll-purıfıed rat striatal synaptosomes was examıned Amphetamıne $(10 \mu \mathrm{M})$ significantly increased phosphorylatıon of a 53 $\mathrm{kDa}$ band that,migrated with authentic neuromodulın in the synaptosomes by $22 \%$ while $500 \mathrm{nM} 12-O$-tetradecanoylphorbol 13 -acetate (TPA) increased neuromodulın phosphorylation by $45 \%$ These data suggest that one injection of amphetamine can increase neuromodulın phosphorylation in rat striatum and that this increase is maintained for at least 1 week following a repeated, sensitizing regimen of amphetamıne Since sensitization can be induced with one dose of amphetamine, it is possible that enhanced neuromodulin phosphorylation could contribute to neurochemical events leading to enhanced release of dopamine and/or behavioral sensitization
\end{abstract}

\section{INTRODUCTION}

In humans, amphetamıne (AMPH) abuse can lead to a psychosis that clinically resembles paranoid schizophrenia and responds fairly rapidly to antipsychotic dopamine receptor blocking drugs Upon discontınuation of drug use, individuals remain hypersensitive to the psychotic effects of the drug for several years $2,22,51,52,54$ In anımals, repeated, intermittent, administration of AMPH results in a sensitization of a number of behaviors, including locomotor and stereotyped behaviors (for review see ref 48), that involve activation of dopaminergic systems Behavioral sensitization to AMPH in rats can develop after only one injection, but is more robust after multıple, intermittent, injections and will develop following a number of different injection regimens ${ }^{46,48}$ After withdrawal from the drug, the sensitization intensifies with time and can persist for up to one year ${ }^{40}$ Although considerable evidence suggests than an action of AMPH at dopamine cell bodies in the midbrain is necessary for induction of sensitization ${ }^{13,23,56}$ the expression of AMPH sensitization resides in dopaminergic terminal areas, such as striatum and nucleus accumbens ${ }^{28} 39,4648,58$ An enhanced stımulus-induced release of dopamine in both striatum and nucleus accumbens has been reported after intermittent treatment with AMPH that exhibits characteristics similar to behavioral sensitization in- 
tensification with one dose, but heightened intensity upon multiple doses, increased activity and persistence after withdrawal ${ }^{39} 464858$ Enhanced AMPH-induced dopamine release after repeated AMPH is expressed in both the rat striatum and nucleus accumbens and could play a role in the expression of sensitization ${ }^{46} 48$ Behavioral sensitization to AMPH exhibits characteristics sımilar to other forms of synaptic plasticity, such as long-term potentiation, in that it develops after intermittent stımulı, is long-lasting, involves an increase in neurotransmitter release and its induction is blocked by $N$-methyl-D-aspartate antagonısts ${ }^{25}$ Additional simllarities in models of synaptic plasticity and AMPH-ınduced behavioral sensitization are morphological changes in pre- and postsynaptic elements ${ }^{473397}$ and alterations in activities involving $\mathrm{Ca}^{2+}$ and/or the endogenous $\mathrm{Ca}^{2+}$-bındıng protein, calmodulın $(\mathrm{CaM})^{192426424360}$ We and others have shown an increased CaM content and altered subcellular localızation of $\mathrm{CaM}$ in striatum and limbic forebrain of rats repeatedly treated with AMPH $^{19414350}$

Heightened phosphorylation in brain of a growth-associated, neural-specific, CaM-binding proteın termed neuromodulin (as well as B-50, GAP-43, p57, F1, pp $\left.46,{ }^{8}\right)$ has been reported in several models of synaptic plasticity, such as long-term potentiatıon ${ }^{32} 37$ and memory formation for passive avoidance in chicks ${ }^{49}$ Neuromodulin is located presynaptically and plays a role in neuronal growth and neurotransmitter release ${ }^{8}$ Neuromodulin phosphorylation has been correlated with neurotransmitter release from both synaptosome and slice preparations $^{1018}$ Due to its low charge-to-mass ratio neuromodulın exhibits apparent molecular masses of between 43 and $67 \mathrm{kDa}$ on SDS-polyacrylamide gels, rather than its exact molecular mass of $24 \mathrm{kDa}^{8}$ Proteın kınase $\mathrm{C}$ (PKC)-mediated phosphorylation of neuromodulin or increased $\mathrm{Ca}^{2+}$ leads to dissociation of CaM from neuromodulin ${ }^{31}$ It has been postulated that neuromodulin sequesters $\mathrm{CaM}$ in the unstimulated cell and releases it upon an increase in intracellular $\mathrm{Ca}^{2+}$ and phosphorylation by $\mathrm{PKC}^{31}$ Since PKC-dependent phosphorylation of neuromodulın has been correlated with synaptic plasticity and may a play a role in neurotransmitter release and CaM localization in a cell, the phosphorylation of endogenous neuromodulin in response to acute or repeated AMPH treatment was investigated To study neuromodulin phosphorylation, the post hoc phosphorylation of neuromodulin in response to exogenous partially-purified PKC was assessed in purified rat striatal synaptic plasma membranes If enhanced neuromodulin phosphorylation is involved in behavioral sensitization and/or the increased dopamine release in response to $\mathrm{AMPH}$, one would predict that neuromodulin phosphorylation would be greater after repeated treatment with AMPH and would persist following withdrawal of the drug Enhanced phosphorylation of neuromodulın could also be detected after acute AMPH, since sensitization has been reported after a single dose of $\mathrm{AMPH}^{\text {ts }}$ We found that neuromodulın phosphorylation was enhanced in striatal synaptic plasma membranes trom rats treated repeatedly with AMPH or in control rats that had received only one acute injection of AMPH Preliminary studies show that AMPH could incredse phosphorylation of a $53 \mathrm{kDa}$ band migratıng with authentic neuromodulin in purified synaptosomes

\section{MATERIALS AND METHODS}

\section{AMPH treatment}

Female Holtzman rats were treated with salıne (SAL) or 25 $\mathrm{mg} / \mathrm{kg}$ AMPH ip twice weekly for 5 weeks One week after the repeated treatment a challenge dose of SAL or AMPH was admınıstered $30 \mathrm{~min}$ before sacrifice such that 4 groups were formed SAL-SAL, SAL-AMPH, AMPH-SAL and AMPH-AMPH In Study 1 the challenge dose of AMPH was $1 \mathrm{mg} / \mathrm{kg}$ and in Study 2 the challenge dose was $25 \mathrm{mg} / \mathrm{kg}$ The lower challenge dose in Study 1 was chosen because the differences in sensitized behavior and AMPH-induced dopamine release are accentuated after a lower challenge dose of AMPH (ref 47, T E Robınson, personal communication) This treatment regimen was shown to result in robust increases in rotational activitv ${ }^{45}$

\section{Preparation of svnaptic plasma membranes}

Striata were dissected within $60 \mathrm{~s}$ of sacrifice and homogenized in $032 \mathrm{M}$ sucrose, $1 \mathrm{mM}$ EGTA $2 \mathrm{mM}$ Tris, pH 7 4, $10 \mu \mathrm{M}$ leupeptın, $10 \mu \mathrm{M}$ pepstatın and $1 \mathrm{mM}$ phenylmethylsulfonyl fluoride (PMSF) In Study 2 the medium included $1 \mu \mathrm{M}$ okadaic acid Synaptic plasma membranes (SPM) were prepared as described by Dokas et al ${ }^{12}$ Briefly a $\mathrm{P} 2$ pellet prepared from an individual striatum (approximately $50-60 \mathrm{mg}$ wet weight) was lysed, centrifuged dt $10000 \times \mathrm{g}$ for $20 \mathrm{~min}$ washed and applied to d sucrose gradient consisting of $40 \mathrm{ml}$ of $04 \mathrm{M}$ sucrose overlaid on $8 \mathrm{ml}$ of $10 \mathrm{M}$ sucrose The gradient was centrifuged at $100,000 \times g$ for $80 \mathrm{~mm}$ in a Beckman SW27 rotor SPM's were collected by dspiration from the interface of the $04 \mathrm{M}$ and $10 \mathrm{M}$ layers, diluted 2- to 3-fold in $10 \mathrm{mM}$ Tris-HCl, pH 75 and $1 \mathrm{mM}$ EGTA and centrifuged in the SW 27 rotor at $100,000 \times g$ for 30 min The final pellet was resuspended in $10 \mathrm{mM}$ Tris buffer $\mathrm{pH} 75$ Approxımatelv $7 \mu \mathrm{g}$ of SPM protein was obtained per mg wet weight tissue

\section{Post hoc phosphorylation assat}

PKC was purified from rat brain as described by Kitano et al ${ }^{27}$ SPMs were phosphorylated in an assay containing $10 \mathrm{mM}$ sodium acetate, $\mathrm{pH} 65,10 \mathrm{mM}$ magnesium acetate, $75 \mu \mathrm{M}\left[\gamma^{3}{ }^{32} \mathrm{P}\right] \mathrm{ATP}(2$ $\mathrm{mCl}$ /assay), $06 \mu \mathrm{g}$ purified $\mathrm{PKC}, 01 \mathrm{mM} \mathrm{CaCl}_{2}$ in a total volume of $75 \mu \mathrm{l}$ ds described by Dokas et al ${ }^{12}$ After $30 \mathrm{~s}$ of incubation, the reaction was terminated by the addition one-third volume of an SDS-containing stop solution containıng $125 \mathrm{mM}$ Tris-HCl, pH 68 $4 \%$ SDS, $10 \%$ glycerol, $0008 \%$ bromphenol blue and $40 \%$ mercaptoethanol In Study 1, SPMs were preincubated in assay buffer (10 $\mathrm{mM}$ sodium acetate, $\mathrm{pH} 65,10 \mathrm{mM}$ magnesium acetate and $01 \mathrm{mM}$ $\mathrm{CaCl}_{2}$ ) for $5 \mathrm{~min}$ at $30^{\circ}$ There was no preincubation in Study 2 Samples were immediately subjected to SDS-PAGE on gels containing either $10 \%$ or $875 \%$ polyacrylamide as indicated with subsequent dutoradiography Results were analyzed by either cuttıng the neuromodulın band and counting the radioactivity or by scannıng 
the films with a Hoefer GS365W scanning densitometer The total peak areas were quantıfied by Gaussian integration using the Hoefer GS365W electrophoresis data system Statistıcal significance was determıned by one way analysis of variance (ANOVA) with post test Bonferronı $t$-test analysis calculated usıng GraphPad Instat

\section{Immunoblotting}

SPM samples subjected to SDS-PAGE were electrophoretıcally transferred to Immobilon-P membranes for $2 \mathrm{~h}$ at $1 \mathrm{~A}$ at $4^{\circ} \mathrm{C}$ in a Transphor Transfer Unıt (Hoefer Scientıfıc) Blots were incubated in $10 \mathrm{mM}$ Tris- $\mathrm{HCl}, \mathrm{pH} 74,150 \mathrm{mM} \mathrm{NaCl}$ with $01 \%$ Tween 20 and $1 \%$ $(\mathrm{w} / \mathrm{v})$ bovine serum albumın (blockıng buffer) for $1-2 \mathrm{~h}$ at $4^{\circ} \mathrm{C}$ The Immobilon membrane was incubated overnight with affinity-purified antıneuromodulın produced in rabbit (obtained from Dr Daniel Storm, Department of Pharmacology, University of Washington) diluted 11000 in blockıng buffer ${ }^{125}$ I-labeled donkey $(1 \mathrm{mCl})$ antırabbit $\mathrm{IgG}$ or ${ }^{125} \mathrm{I}$-protein $\mathrm{A}(1 \mathrm{mCl})$ was used for quantification and autoradıography

\section{PKC assay}

PKC activity of the SPMs was measured using a synthetic substrate peptide, myelin basic proteın ${ }_{4-14}\left(\mathrm{MBP}_{4-14}\right)$, as described by Yasuda et al ${ }^{59}$ Phosphorylation of $\mathrm{MBP}_{4-14}$ by endogenous PKC in the SPM fractions was carried out in plastic tubes in a reaction mixture $(50 \mu \mathrm{l})$ containıng $20 \mu \mathrm{M}$ Tris- $\mathrm{HCl}, \mathrm{pH} 75,5 \mathrm{mM}$ magnesium acetate, $01 \mathrm{mM} \mathrm{CaCl}, 20 \mathrm{mM} \mathrm{ATP}\left(03 \mu \mathrm{Cl}_{2} /\right.$ assay $), 15 \mathrm{mM}$ $\mathrm{MBP}_{4-14}, 05 \mathrm{mg}$ phosphatidyl serıne, $50 \mathrm{ng}$ of diolein and $2 \mu \mathrm{g}$ of SPM protein for $6 \mathrm{~min}$ at $30^{\circ} \mathrm{C}$ The reaction was stopped by spottıng a $40 \mu 1$ alıquot of the mixture onto a piece of $P-81$ paper which was immediately placed in $75 \mathrm{mM} \mathrm{H}_{2} \mathrm{PO}_{4}$ and washed 4 times as described by Yasuda et al ${ }^{59}$ Parallel reactions were conducted in the presence of $1 \mathrm{mM}$ ethyleneglycol-bis-( $\beta$-aminoethyl ether) $N, N, N^{\prime}, N^{\prime}$-tetraacetic acid (EGTA) and in the absence of $\mathrm{MBP}_{4-14}$ Phosphorylation of the specific PKC substrate $\mathrm{MBP}_{4-14}$ was generally 4-5 times that of the non-peptide containıng blank PKC activity was also measured in the $10,000 \times g$ S2 supernatant fraction prepared from striata as described above using $200 \mu \mathrm{g} / \mathrm{ml}$ histone $\mathrm{H} 1$ as substrate and $30 \mu \mathrm{g}$ of S2 protem ${ }^{27}$ The PKC activity of the S2 fraction was determined to be the total activity $\left(\mathrm{CaCl}_{2}\right.$ plus lipıds) minus that activity measured in the presence of $\mathrm{CaCl}_{2}$ All radioactıvity was determıned using $\beta$-scintillation countıng in a Beckman LS8100

\section{Phosphorylation of Percoll-purified synaptosomes}

Percoll-purified striatal synaptosomes from 4 rats were prepared as described by Dunkley et al ${ }^{14}$ Fractions 3 and 4 , enriched with synaptosomes, were combined, washed and resuspended to a protein concentration of $2-3 \mathrm{mg} / \mathrm{ml}$ in oxygenated Krebs Ringer buffer (118 $\mathrm{mM} \mathrm{NaCl}, 47 \mathrm{mM} \mathrm{KCl}, 12 \mathrm{mM} \mathrm{CaCl}, 12 \mathrm{mM} \mathrm{MgCl}_{2}, 249 \mathrm{mM}$ $\mathrm{NaHCO}_{3}, 10 \mathrm{mM}$ glucose, oxygenated for $1 \mathrm{hr}$ and brought to $\mathrm{pH} 74$ at $\left.37^{\circ} \mathrm{C}\right)$ Synaptosomes were prelabeled with ${ }^{32} \mathrm{P}_{1}(05 \mathrm{mCl} / \mathrm{ml})$ for $45 \mathrm{~min}$ at $37^{\circ} \mathrm{C}$ in Krebs-Ringer buffer The synaptosomes were then incubated with $10 \mu \mathrm{M}$ AMPH, $500 \mathrm{nM} 12$ - $O$-tetradecanoylphorbol 13-acetate (TPA) or buffer for 10 min In some experıments synaptosomes were incubated with Krebs-Ringer butfer or high $\mathrm{K}^{+}$buffer $(62 \mathrm{mM} \mathrm{KCl}$ and $857 \mathrm{mM} \mathrm{NaCl}$ ) for $30 \mathrm{~s}$ The reaction was stopped with one-fourth volume of an SDS-buffer solution containing 200 $\mathrm{mM}$ Tris-HCl, $\mathrm{pH} 68,8 \%$ SDS, $28 \%$ glycerol, $01 \%$ bromphenol blue, $77 \mathrm{mM}$ mercaptoethanol and $6 \mathrm{mM}$ EGTA and was subjected to SDS-PAGE on gels containing $875 \%$ polyacrylamıde with subsequent autoradıography Results were analyzed by either by scanning the peaks using a Hoefer GS365W scanning densitometer as described above or cutting the neuromodulın band and counting the radıoactıvity The peak areas were quantıfıed by Gaussıan integration using the Hoefer GS365W electrophoresıs data system Peak areas were always compared with those of controls run on the same gel Statıstical significance was determined by one way analysis of variance (ANOVA) with posttest Bonferronı $t$-test analysis calculated using GraphPad Instat and by a two-tall Student's $t$-test or Wilcoxan signed-rank test

\section{Materials}

AMPH was purchased from The University of Michigan Laboratory of Animal Medicine Leupeptın, pepstatın, phenylmethylsulfonyl fluorıde, TPA, hıstone $\mathrm{H} 1$, phosphatıdylserıne, dioleın, high molecular weight standards, BSA and Tween were obtained from Sigma Chemical Co (St Lours, MO) Okadaic acid and $\mathrm{MBP}_{4-14}$ were obtained from UBI Biochemicals (Lake Placid NY) P-81 paper was obtaned from Whatman (Maidstone, UK), Percoll from Pharmacia (Upsalla, Sweden) and Immobilon from Millipore (Bedford, MA) ${ }^{125}$ I-labeled donkey anti-rabbit $\mathrm{IgG}$ and ${ }^{125} \mathrm{I}$-protein $\mathrm{A}$ were purchased from Amersham (Arlıngton Heights, IL) $\left[\gamma-{ }^{32} \mathrm{P}\right]$ ATP (spec act $>4000 \mathrm{Cl} / \mathrm{mmol}$ ) was from ICN (Irvine, CA) Affinity-purified rabbit antıneuromodulın was the generous gift of Dr Daniel Storm, Department of Pharmacology, Universıty of Washıngton Purıfied rat brain neuromodulin was generously donated by Dr Linda Dokas, Department of Biochemistry, Medical College of Ohıo

\section{RESULTS}

\section{Effect of EGTA on phosphorylation of neuromodulin}

SPM preparations were used to assess phosphorylation of neuromodulin because neuromodulin is a prominent phosphorylated protein in SPM and is readly detected (Fig 1) The apparent molecular weight of neuromodulin on SDS-PAGE with $10 \%$ polyacrylamide was $48 \mathrm{kDa}$ In later experiments performed on $875 \%$ polyacrylamide gels, which we found gave greater separation of the proteins, neuromodulın appeared to have a molecular weight of 51-53 kDa Dephosphorylation of neuromodulin during preparation of the SPMs, however, could confound the results The ability of EGTA to reduce the endogenous dephosphorylation of


Fig 1 Localization of neuromodulin in striatal synaptic plasma membranes Rat striatal SPMs were prepared and phosphorylated in the presence of partially purified PKC and $\left[\gamma-{ }^{32}\right.$ P ATP as described in Methods and subjected to SDS-PAGE on gels containung $10 \%$ polyacrylamıde Lane 1 high molecular weight standards (myosin, $205 \mathrm{kDa}, \beta$-galactosidase, $116 \mathrm{kDa}$, phosphorylase $\mathrm{B}, 974 \mathrm{kDa}$, bovine plasma albumın, $66 \mathrm{kDa}$, egg albumın, $45 \mathrm{kDa}$, carbonıc anhydrase, $29 \mathrm{kDa}$ ), Lane 2 purified rat brain neuromodulin (10 $\mu \mathrm{g}$ ), Lanes 3 and $427 \mu \mathrm{g}$ of phosphorylated SPM Neuromodulın is one of the most prominent phosphorylated bands in the SPM preparation 

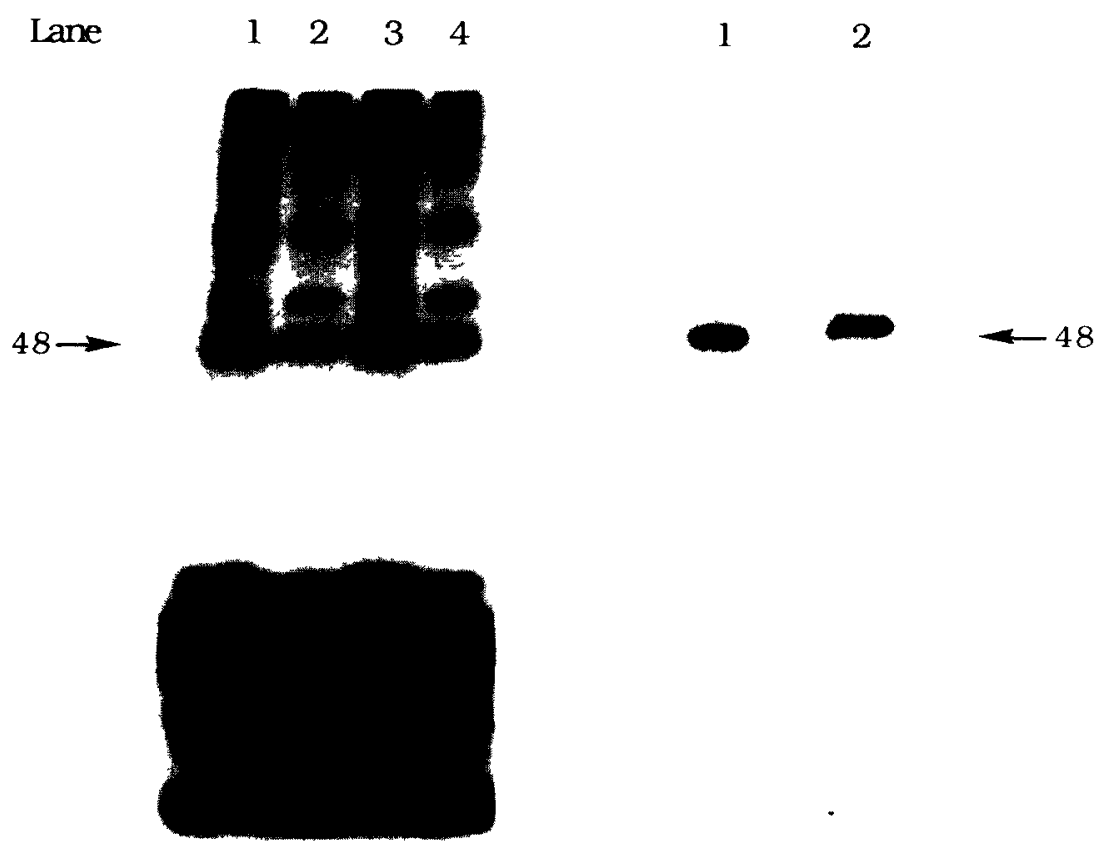

$\begin{array}{rcccc}\text { SPM \# } & 1 & 2 & 1 & 2 \\ \text { Prep mEGTA } & - & + & - & + \\ \text { Assay tume(sec) } & 20 & 20 & 200 & 200\end{array}$

Fig 2 A in vitro phosphorylation by PKC of SPMs prepared in the absence (SPM \#1) and presence (SPM \#2) of EGTA 1 mM EGTA was included in the buffers in the preparation of SPM \#2 Lane 1 SPM \#1, 20 s incubation Lane 2 SPM \#2, 20 s incubation Lane 3 SPM \#1 200 s incubation Lane 4, SPM \#2 $200 \mathrm{~s}$ incubation B immunoblots for neuromodulin contained in $15 \mu \mathrm{g}$ of SPM \#1 (lane 1) and SPM \#2 (lane 2) Samples of SPM \#1 and \#2 were subjected to immunoblottıng using affinity-purified antibody to neuromodulın and [ $\left.{ }^{125} 1\right]$ protein $A$ for detcction The $\mathrm{cpm}$ of $\left.{ }^{125} \mathrm{I}\right]$ protein A for the samples are $2677 \mathrm{cpm}$ for SPM \#1 and $2916 \mathrm{cpm}$ for SPM \#2 showing that the detectable neuromodulin in the two preparations is the same



Fig 3 Post hoc phosphorylation of striatal SPMs from female rats treated with salıne (S) or repeated intermittent AMPH (A) twice weekly for 5 weeks, as described in Materials and Methods and given a challenge dose ot either salıne or AMPH such that four groups were formed S-S S-A, A-S A-A Samples were phosphorylated in the presence of partially purified PKC and $\left[\gamma-{ }^{2}\right.$ P]ATP and subjected to SDS-PAGE on gels contanıng $875 \%$ polyacrylamıde as described in Methods Each lane contains $27 \mu \mathrm{g}$ protein Shown are the results for 3 different sets of anımals Immunoblots for neuromodulın in the SPMs $(15 \mu \mathrm{g})$ using [ $\left.{ }^{125} \mathrm{I}\right]$ donkey anti-rabbit for detection are shown above the SDS gels Only one band was present upon immunoblottıng 
neuromodulın was assessed since neuromodulin is a substrate for the $\mathrm{Ca}^{2+} / \mathrm{CaM}$ dependent phosphatase, calcineurın $^{30}$ Striata were homogenized in $032 \mathrm{M}$ sucrose containing protease inhibitors without (SPM \#1) and with $1 \mathrm{mM}$ EGTA (SPM \#2) (Fig 2) SPMs were prepared and phosphorylated in the presence of purlfied PKC and $\left[\gamma_{-}{ }^{32} \mathrm{P}\right] \mathrm{ATP}$ in the post hoc phosphorylation assay In this assay, a greater incorporation of ${ }^{32} \mathrm{P}$ into the neuromodulin band would signify that the endogenous neuromodulin contained less phosphate As shown in Fig 2A, SPMs prepared in the presence of $1 \mathrm{mM}$ EGTA (SPM \#2) incorporated less ${ }^{32} \mathrm{P}$ in the presence of purified PKC than samples prepared without EGTA suggestıng that the endogenous neuromodulin in those samples contained more phosphate The neuromodulin immunoblot in Fig 2B demonstrates that the amount of immuno-detectable neuromodulın per unit protein was the same in SPMs prepared in the presence (SPM \#2) or absence of EGTA (SPM \#1) The cpm of $\left[{ }^{125} \mathrm{I}\right]$ protein A for the blots are $2677 \mathrm{cpm}$ for $15 \mu \mathrm{g}$ of SPM 1 (SPM \#1) and $2916 \mathrm{cpm}$ for $15 \mu \mathrm{g}$ of SPM 2 (SPM \#2) The recovery of SPM protein was not altered by the presence of EGTA in the preparation buffers Note that there was no significant dephosphorylation of neuromodulin in a $200 \mathrm{~s}$ assay (lanes 3 and 4) as compared to a $20 \mathrm{~s}$ assay (lanes 1 and 2) regardless of whether the SPMs were prepared in the presence or absence of EGTA

Post hoc phosphorylation of neuromodulin in stratal SPMs prepared from rats given repeated, intermittent $A M P H$ or $S A L$

The phosphorylated state of endogenous neuromodulin was determined in striatal SPMs prepared from rats treated intermittently with SAL or AMPH using the post hoc phosphorylation assay In Study 1, there was a decreased ability of neuromodulin to be phosphorylated in the post hoc assay with purified PKC and $\left[\gamma-{ }^{32}\right.$ P $]$ ATP in SPMs prepared from rats recelving elther acute treatment with $1 \mathrm{mg} / \mathrm{kg}$ AMPH or repeated treatment with $25 \mathrm{mg} / \mathrm{kg}$ AMPH Autoradiographs showing phosphorylation of SPMs from 3 different groups of rats are shown in Fig 3 To quantify the ${ }^{32} \mathrm{P}$ incorporated into neuromodulin, the bands corresponding to purified neuromodulin were cut and counted As shown in Table I, the ${ }^{32} \mathrm{P}$ incorporation into those bands was significantly decreased in the SAL-AMPH, AMPH-SAL and AMPH-AMPH groups There was no significant difference in the ${ }^{32} \mathrm{P}$ incorporation among any group that received AMPH The decrease in incorporation of ${ }^{32} \mathrm{P}$ in the post hoc assay suggests that both acute and repeated AMPH treatment increased the in vivo phosphorylation of neuro-

\section{TABLE I}

Inutro phosphorylation and immunoblot alues for neuromodulin in striatum from rats treated with acute or repeated $A M P H$

${ }^{a}$ Female Holtzman rats $(n=6)$ were treated with repeated salıne (S) or amphetamine (A) and given a challenge dose of $S$ or $1 \mathrm{mg} / \mathrm{kg} \mathrm{A}$ before sacrifice as described for Study 1 in Materials and Methods The first initial represents the repeated treatment and the second represents the challenge treatment Bands in the SDS-PAGE corresponding to the $R_{\mathrm{f}}$ of purified NM were cut and counted after phosphorylation in the back-phosphorylation assay $\left({ }^{32} \mathbf{P}\right)$ as were bands containing ${ }^{125}$ I-secondary antibody antibody from $1 \mathrm{~m}$ munoblots For ${ }^{32} \mathrm{P}$ values ANOVA, $P<00001$ In post analysis Bonferron $t$-tests $* P<001$ for A-S and A-A as compared to S-S and $P<005$ for S-A as compared to S-S ${ }^{125}$ I-values were not significantly different, ANOVA, $P=056$

${ }^{\mathrm{b}}$ Female Holtzman rats $(n=5)$ were treated with repeated amphetamıne (A) or salıne (S) and challenged with $S$ or $25 \mathrm{mg} / \mathrm{kg} \mathrm{A}$ as described for Study 2 in Materials and Methods Results were analyzed using densitometry as described in Materials and Methods For densitometry values $P<002$ by ANOVA In post analysis Bonferronı $t$-test ${ }^{* *} P<005$ for S-A and A-S as compared to S-S

\begin{tabular}{llll}
\hline $\begin{array}{l}\text { Treatment } \\
\text { group }\end{array}$ & $\begin{array}{l}\text { Study } 1^{a} \\
\begin{array}{l}{ }^{32} P \\
(c p m)\end{array}\end{array}$ & $\begin{array}{l}\text { Study } 2^{b} \\
(\text { cpm })\end{array}$ & $\begin{array}{l}\text { Densttometry calues } \\
\left.\text { (Unts } \times 10^{-3}\right)\end{array}$ \\
\hline S-S & $293 \pm 5$ & $8613 \pm 581$ & $478 \pm 15$ \\
S-A & $231 \pm 15^{*}$ & $7807 \pm 680$ & $268 \pm 3^{* *}$ \\
A-S & $201 \pm 16^{*}$ & $8773 \pm 479$ & $365 \pm 27^{* *}$ \\
A-A & $199 \pm 11^{*}$ & $7948 \pm 537$ & $416 \pm 27$ \\
\hline
\end{tabular}

modulın Although the challenge dose of $1 \mathrm{mg} / \mathrm{kg}$ AMPH was able to increase neuromodulin phosphorylation in control SAL-treated rats, challenge with AMPH produced no further change in neuromodulin phosphorylation in rats repeatedly treated with AMPH To assess whether AMPH altered the amount of neuromodulın in the SPMs, Immunoblots were performed using affinity-purıfıed antıbody to neuromodulın Neuromodulin immunoreactivity was detected with ${ }^{125} \mathrm{I}$ labeled donkey ant1-rabbit IgG The immunoblots for neuromodulin in the SPMs are shown above the SDS gels in Fig 3 Only one band was present upon immunoblotting The bands were cut and counted and the results are shown in Table I The amount of immuno-detectable neuromodulin was not altered by AMPH treatment further indicatıng that the decreased ${ }^{32} \mathrm{P}$ incorporation represents an alteration in the phosphorylated state of neuromodulın in vivo

To further reduce dephosphorylation of neuromodulin during preparation of SPMs as a factor in our results, the experiment was repeated including $1 \mu \mathrm{M}$ okadaic acid with $1 \mathrm{mM}$ EGTA in SPM preparation buffers (Study 2) In addition, the challenge dose of acute AMPH was increased to $25 \mathrm{mg} / \mathrm{kg}$ to correspond with the dose of AMPH given repeatedly for 5 weeks The experiments were performed as described above but the results were analyzed by densitometry as described in Methods As shown in Table I, essentially the same results were achieved as those in Study 1 


\section{TABLE II}

$P K C$ actult in stratal fractions from rats treated with acute or lepeated AMPH

Female Holtzman rats were treated with salıne (S) or amphetamıne (A) and challenged with S or $25 \mathrm{mg} / \mathrm{kg} \mathrm{A}$ as described for Study 2 in Materids and Methods PKC activity was measured in striatal SPM or S2 cytosol as described in Materials and Methods $n=4$

\begin{tabular}{|c|c|c|c|}
\hline \multirow{2}{*}{$\begin{array}{l}\text { Treatment } \\
\text { group }\end{array}$} & \multicolumn{2}{|c|}{$S P M(p m o l / m i n / m g$ prot $\pm S E M)$} & \multirow[t]{2}{*}{ S2crtosol } \\
\hline & Total & $\mathrm{Ca}^{2+}$ dependent & \\
\hline$S-S$ & $459 \pm 85$ & $264 \pm 90$ & $939 \pm 22$ \\
\hline$S-A$ & $494 \pm 79$ & $261 \pm 57$ & $821 \pm 41$ \\
\hline A.S & $661 \pm 105$ & $401 \pm 68$ & $964 \pm 149$ \\
\hline$A-A$ & $424 \pm 74$ & $248 \pm 74$ & $1103 \pm 157$ \\
\hline
\end{tabular}

The ability of neuromodulin to be phosphorylated in the post hoc assay was reduced in SPMs from control rats receiving a challenge dose of $25 \mathrm{mg} / \mathrm{kg}$ AMPH or trom rats receiving repeated AMPH In this exper1ment, there was not a significant reduction in phosphorylation in the AMPH-AMPH group, but it demonstrated again that a challenge dose of AMPH does not elicit further neuromodulin phosphorylation in rats that have received repeated AMPH

To determine whether the altered neuromodulın phosphorylation was due to increased PKC activity, this activity was measured in SPM and soluble fractions trom the four treatment groups PKC activity in the SPMs was determıned using the specific PKC substrate $\mathrm{MBP}_{4-14}$ since very little activity could be measured using histone $\mathrm{Hl}$ as a substrate The PKC activity in the SPMs was variable among the four groups but the results in Table II suggest that there was no significant difference in PKC activity among the groups Therefore netther repeated AMPH nor a challenge dose of AMPH appeared to alter the PKC activity To determine whether AMPH treatment would alter PKC actıvity in general, PKC activity in the soluble S2 fraction

\section{TABLE III}

Phosphonlation of neuromoduln bv AMPH, TPA and high $K^{+} \mathrm{m}$ percoll-purfied rat striatal synaptosomes

Percoll-purified striatal synaptosomes were equilibrated with ${ }^{32} \mathbf{P}_{1}$ and incubated with $10 \mu \mathrm{M}$ AMPH, $500 \mathrm{nM}$ TPA for $10 \mathrm{~m}$ n or 62 $\mathrm{mM} \mathrm{KCl}$ for $30 \mathrm{~s}$ as described in Materials and Methods Results were analyzed by scanning the neuromodulın band with densitometry ds described in Materials and Methods a $P<0007$ as determined by a 2-tall parred $t$-test ${ }^{b} P<0003$ as determined by a 1-tall paired $t$-test ' $P<0008$ as determıned by a Wilcoxon signed rank test

\begin{tabular}{lcll}
\hline Treatment & $n$ & $\begin{array}{l}\text { Densitometr lalues } \\
\left(\text { Units } \times 10^{-3}\right)\end{array}$ & ${ }^{\circ}$ Control \\
\hline Buffer & 9 & $6 \pm 08$ & $125 \pm 8$ \\
AMPH & 9 & $73 \pm 08^{\mathrm{a}}$ & \\
Buffer & 4 & $69 \pm 1$ & $145 \pm 11$ \\
TPA & 4 & $97 \pm 1^{\mathrm{b}}$ & \\
Buffer & 1 & 116 & 181 \\
High K $^{+}$ & 1 & 21 & \\
\hline
\end{tabular}

was measured As shown in Table III, there was no significant difference in activity among any of the groups

\section{Phosphorylation of a $53 \mathrm{kDa}$ protein in Percoll-purfied rat stratal synaptosomes}

The results of both Study 1 and Study 2 indicated that an acute in vivo dose of AMPH could increase the phosphorylation of neuromodulın in SPMs To determine whether this effect of AMPH could be measured
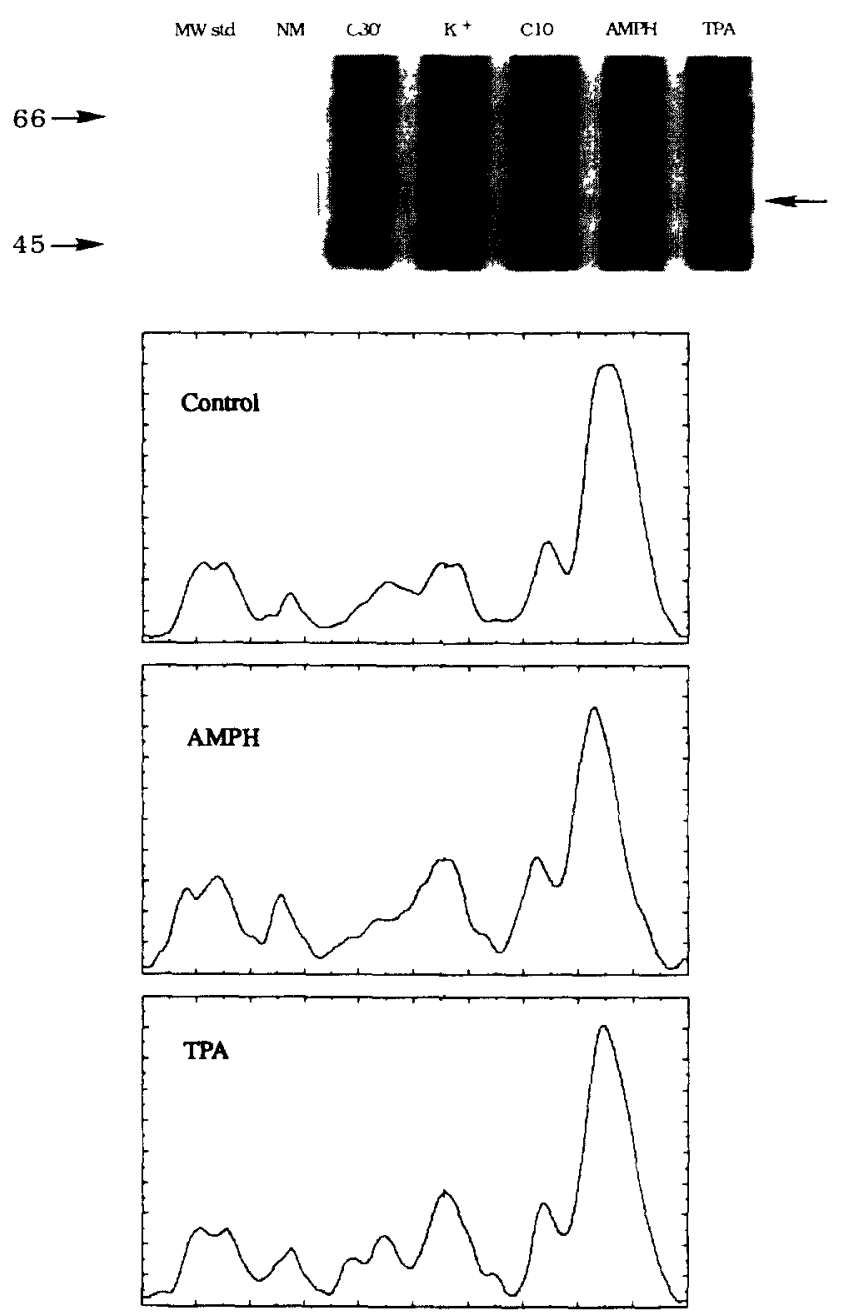

Fig 4 A nturomodulın phosphorvlation in Percoll-purıfied stridtal synaptosomes After equilibration with ${ }^{32} \mathrm{P}_{1}$, synaptosomes were incubated with either buffer or $62 \mathrm{mM} \mathrm{KCl}$ for $30 \mathrm{~s}$ or buffer $10 \mu \mathrm{M}$ AMPH or $500 \mathrm{nM}$ TPA for $10 \mathrm{~min}$ as described in Materials and Methods The reaction was stopped with SDS-stop buffer and subjected to SDS-PAGE on gels containing $875 \%$ actvlamide with subsequent autoradıgraphy Lane 1 molecular weight markers Lane $2,5 \mu \mathrm{g}$ purified rat brain neuromodulın Lane 3, buffer control, $30 \mathrm{~s}\left(\mathrm{C} 30^{\prime \prime}\right)$ Lane $462 \mathrm{mM} \mathrm{KCl}, 30 \mathrm{~s}\left(\mathrm{~K}^{+}\right)$Lane 5 buffer control, $10 \mathrm{~min}\left(\mathrm{Cl}^{\prime \prime}\right)$ Lane $610 \mu \mathrm{M}$ AMPH $10 \mathrm{~min}$ Lane $7,500 \mathrm{nM}$ TPA, $10 \mathrm{~min}$ Under these conditions, purified neuromodulin ran with an appdrent molecular weight of $53 \mathrm{kDa} B$ densitometric scans of phosphoproteins in lanes 5,6 and 7, 10 min incubation tımes with buffer (top), $10 \mu \mathrm{M}$ AMPH (middle) or $500 \mathrm{nM}$ TPA (bottom) The neuromodulin peak is marked with a dotted line Results were analyzed by Gaussian integration with the GS365W densitometric program as described in Materials and Methods 
more directly, prelımınary experıments were undertaken to examıne the ability of AMPH to increase neuromodulin phosphorylation in an isolated synaptosomal preparation Percoll-purıfıed synaptosomes were equilibrated with ${ }^{32} \mathrm{P}$, and then incubated with buffer, $10 \mu \mathrm{M}$ AMPH or $500 \mathrm{nM}$ TPA In one experiment, the effect of depolarization with high $\mathrm{K}^{+}$on neuromodulın phosphorylation was assessed Phosphorylation of a 53 $\mathrm{kDa}$ band migratıng with authentıc neuromodulın was assessed by scanning densitometry of the films and, in some experiments, by cuttıng the band from the gel and counting radioactivity The results in Table III show that $10 \mu \mathrm{M}$ AMPH had some effect in increasing phosphorylation of the $53 \mathrm{kDa}$ band Addition of 10 $\mu \mathrm{M}$ AMPH to the synaptosomes significantly increased the phosphorylation of the $53 \mathrm{kDa}$ neuromodulın band by $25 \%$. TPA averaged a $45 \%$ increase in phosphorylation of the $53 \mathrm{kDa}$ neuromodulın band and $\mathrm{K}^{+}$depolarization increased the phosphorylation by $81 \%$ Shown in Fig 4A is an autoradiograph demonstratıng phosphorylation of the $53 \mathrm{kDa}$ band by $62 \mathrm{mM} \mathrm{KCl}, 10$ $\mu \mathrm{M}$ AMPH and $500 \mathrm{nM}$ TPA A lane containing authentic neuromodulin is also shown The densitometry traces corresponding to the autoradıograph for the control, AMPH and TPA incubations are shown in Fig $4 \mathrm{~B}$ Increased phosphorylation of the $53 \mathrm{kDa}$ neuromodulin band is clearly shown in response to AMPH and TPA Integration values for the densitometry tracings are given in Table III and show a significant increase in phosphorylation of neuromodulin by both AMPH and TPA In 5 of the AMPH experiments, the ${ }^{32}$ P-containıng $53 \mathrm{kDa}$ neuromodulın band was cut and counted Values for ${ }^{32} \mathrm{P}$ in CPM were buffer, $307 \pm 52$, AMPH, $385 \pm 72, \mathrm{p}<005$ as determined by a 2-talled Student's $t$-test

\section{DISCUSSION}

A post hoc phosphorylation assay was devised to determine the effect of repeated AMPH, given in an intermittent regimen that results in behavioral sensitization, on the in vivo phosphorylated state of neuromodulın in rat striatum Our results suggest that one injection of AMPH can increase the phosphorylation of neuromodulin and the heightened phosphorylation remains at least one week after withdrawal from a regimen of repeated, intermittent, AMPH The phosphorylated state after repeated AMPH appears 'maximal' and stable such that a challenge dose of AMPH 1 week later elicits no further change in phosphorylation of neuromodulin Although dephosphorylation of neuromodulın durıng preparatıon of SPMs could confound these results, our experiments suggested that inclusion of EGTA in the homogenization buffer reduced the dephosphorylation of neuromodulın during SPM preparation These results are consistent with those of Meırı and Burdıck ${ }^{35}$ who found that dephosphorylation of neuromodulın in growth cones was prevented by EGTA but not okadaic acid Since, however, neuromodulın has been shown to be dephosphorylated by proteın phosphatases 1 and $2 A^{20}$ in synaptic membranes, the experıment was repeated including $1 \mu \mathrm{M}$ okadaic acid which would inhibit both phosphatases The results of both studies were comparable An alternative explanation of the data is that EGTA treatment could increase binding of endogenous CaM to neuromodulın, which could block the post hoc phosphorylation of the protein However, this explanation is unlikely for two reasons First, striata from SAL- and AMPH-treated anımals were both homogenized with EGTA in exactly the same way Second, the preincubation of membranes in a calcium-containing buffer in Study 1 should have dissociated endogenous CaM, permittıng phosphorylation by PKC In Study 2, SPMs were not preincubated to reduce the possibility of phosphatase action on endogenous neuromodulın during the preincubation period Results from Study 1 and Study 2 were essential the same

The post hoc assays were conducted using an excess of partially purified PKC Recent studies have shown that neuromodulin in cultured neurons and in neonatal rat brain can be phosphorylated in vivo at 3 sites, only one of which, serine 41 , is phosphorylated by $\mathrm{PKC}^{55}$ Neuromodulın can be phosphorylated in vitro by caseın kınase $\mathrm{II}^{3}$ Phosphorylation at serine 41 is important in the regulation of local concentrations of calmodulın ${ }^{31}$ and may play a role in modulating neurotransmitter release $^{1844}$ The relatively modest changes in phosphorylation could be due to the fact that not all neurons in the striatum are affected by the acute or repeated AMPH, and the fact that only one-third of the possible phosphorylation sites in neuromodulin are affected by PKC Although the $n$ was low and the results variable, measurement of PKC activity suggested that AMPH treatment did not increase PKC activity It is possible that there is a transient increase in PKC elicited by AMPH that was not detected by our assay, or that a change in phosphatase activity is responsible for the alteration of neuromodulın phosphorylation

Many studies have demonstrated changes in neuromodulın content, localızatıon or phosphorylation associated with synaptic plasticity and nerve growth ${ }^{8,18} 3853$ Increases in neuromodulin phosphorylation have been shown to accompany long-term potentiation ${ }^{1732.37}$ and the one-trial passive avoidance learning task in chıcks ${ }^{49}$ The molecular mechanisms by which neuromodulın 
modifies synaptic function in the adult brain, however, dre unclear Although neuromodulin is highly concentrated in areas such as the neocortex and hippocampus $^{8}$, neuromodulin mRNA is also expressed at high levels in catecholamınergic neurons in rat brainstem ${ }^{5}$ This strongly suggests that it is involved in physiological processes, such as neurotransmitter release, signal transduction or other responses of functional plasticity, that regulate the synaptic function of the catecholamınes There are several ways in whıch neuromodulın could alter synaptic function durıng AMPH sensitization One possible role is modulation of neurotransmitter release Enhanced stımulus-induced dopamine release has been demonstrated in both rat striatum and nucleus accumbens after repeated AMPH treatment Both $\mathrm{AMPH}-$ and $\mathrm{Ca}^{2+}$-requiring $\mathrm{K}^{+}$. stımulated release are increased $^{6}$ The increased dopamine releasability is expressed after a single injection of AMPH, is evident only after intermittent dosage regimens, persists for months after discontinuation of AMPH and is strengthened with greater time of withdrawal ${ }^{46} 48$ These characteristics are expressed by many behaviors in AMPH-induced sensitization PKCmediated phosphorylation of neuromodulin has been postulated to play a modulatory role in neurotransmitter release $\mathrm{i}^{1844}$ Phosphorylation of neuromodulın can be stimulated by depolarization-dependent $\mathrm{Ca}^{2+}$ influx, receptor activation or phorbol esters ${ }^{1844}$ and has been correlated with neurotransmitter release from synaptosomes and hippocampal slices ${ }^{18}$ In a study in streptolysin- $O$-permeabilized synaptosomes, however, anti-neuromodulın antibodies, which inhibit neuromodulın phosphorylatıon by PKC, ınhıbıted depolarızation-evoked neurotransmitter release but not phorbol ester-ınduced neurotransmitter release ${ }^{11}$ This result must be interpreted with caution since neuromodulın may not be involved in mediation of release, but may have a role in priming or modulation of release ${ }^{44}$ In addition, permeabilized synaptosomes, while retaining some function, may not maintain all functions of an untreated, healthier synaptosome The fact that an AMPH challenge had no further effect on neuromodulın phosphorylation in rats repeatedly treated with AMPH supports the concept that neuromodulın phosphorylation does not mediate the immediate release of dopamine or the immediate expression of behavioral sensitization An AMPH challenge given to rats sensitized to AMPH elicits enhanced dopamıne release and an exaggerated behavioral response (see refs 47,48 ) Although enhanced release of dopamine may play a role in mediatıng the behavioral sensitization to AMPH, it is unlikely to be the sole mechanısm underlyıng this phenomenon ${ }^{29}$
Morphological changes in synapses also accompany expressions of synaptic plasticity ${ }^{44957}$ Uranova et $\mathrm{al}^{57}$ found an increase in the area of presynaptic terminals and length of postsynaptic density in axodendritic and axo-spinous synapses in rat medial pretrontal cortex Similar studies were not performed in striatum Neuromodulin is primarily presynaptic ${ }^{18}$ in neurons and associated with a membrane skeleton in cells $^{36}$ Although molecular events leading to morphological changes in synapses are not known, the known association of neuromodulin with reactive synaptogenesis ${ }^{38}$ and nerve growth suggests it could have a role in this process

Neuromodulin could also affect signal transduction in the neuron through its interaction with Go or its regulation of local CaM concentrations ${ }^{8}$ A change in PKC-mediated phosphorylation of neuromodulın may lead to increased avalable CaM in the neuron In vitro studies have shown that PKC-mediated phosphorylation of neuromodulin on serine 41 leads to a dissociation of CaM, since serine 41 borders the CaM-binding site $^{1}$ Although a direct correlation between phosphorylation of serine $41 \mathrm{in}$ neuromodulin and CaM dissociation has not been demonstrated in vivo, CaM has been shown to bind to neuromodulin in membranes" We have shown that stımulation of PKC leads to a membrane-to-cytosol redistribution of calmodulin in human neuroblastoma SK-N-SH cells, which contain neuromodulın ${ }^{34}$ An increase in CaM in the cell could lead to a rise in activation of various CaM-dependent enzymes An increase in neuromodulin phosphorylation could enhance neurotransmitter release through dissociation of CaM, which would activate CaM-dependent protein kınase II (CaM-kınase II) CaM-kınase II, which has been localized in synaptosomes ${ }^{15}$, could increase the phosphorylation of the actin-binding vesicle-associated protein, synapsin I Increased CaMKinase II-mediated phosphorylation of synapsin I has been demonstrated to increase neurotransmitter release $^{21}$ Phosphorylation of synapsin I releases the vesicle from cytoskeletal constraints and may allow more vesicles to migrate toward the active zone in the neuron We have demonstrated an increase in CaM in Percoll-purified striatal synaptosomes prepared from rats treated with repeated, intermittent, AMPH (Gnegy and Farrell, data not shown)

Our data suggest that AMPH could directly elicit phosphorylation of a $53 \mathrm{kDa}$ that migrated with authentic neuromodulin in d synaptosomal preparation Even at $10 \mu \mathrm{M}$ AMPH, the effect was modest as compared to that of TPA and high $\mathrm{K}^{+}$The mechanism by which this might occur is unknown TPA directly activates PKC and the $\mathrm{K}^{+}$-induced influx of $\mathrm{Cd}^{2+}$ 
would increase CaM dissociation and stımulate phosphorylation by PKC AMPH, however, is taken up into the synaptosome through the catecholamine transporter and appears to release cytosolic and vesicular catecholamines through passive diffusion ${ }^{16}$ PKC phosphorylation of neuromodulın is primarily by the $\beta$-isoform, which is activated by $\mathrm{Ca}^{2+}$ and diacylglycerol It is possible that AMPH could either alter ionic fluxes in the synaptosome to cause a change in $\mathrm{Ca}^{2+}$ or change enzyme activities such as phospholipases to increase production of diacylglycerol ${ }^{44}$ Alternatively, AMPH could release a substance which could then act upon the synaptosome to elicit neuromodulin phosphorylation Specific saturable sequestration sites for AMPH in synaptosomes, espectally at higher concentrations such as $10 \mu \mathrm{M}$, that may interact with $N$-acetylaspartate and abolish a transsynaptosomal $\mathrm{pH}$ gradient have been reported ${ }^{61}$ There could be many, as yet unknown, actions of AMPH in a synaptosome Since neuromodulın is phosphorylated by a protein kınase other than $\mathrm{PKC}^{55}$, this unknown enzyme could be activated by AMPH Further, although the $53 \mathrm{kDa}$ band migrated with purified neuromodulin, we cannot state unequivocally that the band is neuromoduln at this time It could be another protein comigrating with neuromodulın We are presently conductıng exper1ments to further characterize this effect of AMPH on the $53 \mathrm{kDa}$ band and determine absolutely that it is neuromodulin that is being phosphorylated

In summary, the results of the post hoc phosphorylation assays suggests that both acute, in vivo, AMPH and repeated, intermittent, AMPH lead to an increase in neuromodulın in rat striatal synaptic plasma membranes Thus neuromodulin phosphorylation could contribute to the synaptic changes and plasticity that occur as a result of acute and repeated AMPH treatment and may play some role in behavioral sensitizaton that develops to AMPH These also demonstrates a similarity in neurochemical events in several models of synaptıc plasticity, including long-term potentiation and other models of memory

Acknowledgements The authors are grateful to Dr Terry Robınson and Dr Jill Becker (Department of Psychology, University of Michıgan) and to Dr Linda Dokas (Department of Biochemistry, Medical College of Ohıo) for their helpful discussions over the course of this study We would also like to thank Dr Daniel Storm, Dr Linda Dokas and Dr Karen Leach for their generous gifts of neuromodulın antıbody, purified neuromodulın and proteın kınase $C$, respectıvely This work was supported by the Grant DA05066 from the National Institutes for Drug Abuse

\section{REFERENCES}

1 Alexander, K A , Wakım, B, Doyle, G S, Walsh, K A and Storm, $D \mathrm{R}$, Identıfication and characterization of the calmodulın-bınd- ing domain of neuromodulın, a neurospecific calmodulın-bınding protein, $J$ Biol Chem, 263 (1988) 7544-7549

2 Angrist, B, Sathananthan, G, W 1 lk, S and Gershon, S, Amphetamine psychosis behavioral and biochemical aspects, J Psvchiat Res, 11 (1974) 13-23

3 Apel, E D . Litchfield, D W , Clark, R H , Krebs, E G and Storm, D R, Phosphorylation of neuromodulın (GAP-43) by caseın k1nase II Identification of phosphorylation sites and regulation by calmodulın, $J$ Biol Chem, 266 (1991) 10544-10551

4 Batley, $\mathrm{CH}$ and Chen, M, Morphological basis of long-term habituation and sensitization in Aplvsia, Science, 220 (1983) 9193

5 Bendottı, C Servadio, A and Samanın, R, Distribution of GAP-43 mRNA in the brain stem of adult rats as evidenced by in situ hybridization Localızation within monoaminergic neurons, $J$ Neurosct, 11 (1991) 600-607

6 Castenada, E, Becker, J and Robinson, TE, The long-term effects of repeated amphetamıne treatment in vivo on amphetamıne, $\mathrm{KCl}$ and electrical stımulation evoked striatal dopamine release in vitro, Life $S_{C l}, 42$ (1988) 2447-2456

7 Chang, F-L and Greenough, W T, Transient and enduring morphological correlates of synaptic activity and efficacy change In the rat hippocampal slice, Brain Res, 309 (1984) 35-46

8 Coggins, P J and Zwiers, H, B-50 (GAP-43) biochemistry and functional neurochemistry of a neuron-specific phosphoprotein, $J$ Neurochem, 56 (1991) 1095-1106

9 De Grdan, P N E, Oestreicher, A B, De Wit, M, Kroef, M, Schrama, LH and Gispen, WH, Evidence for the binding of calmodulın to endogenous B-50 (GAP-43) in native synaptosomal plasma membranes, $J$ Neurochem, 55 (1990) 2139-2141

10 Dekker, L V, De Graan, PNE De Wit, M Hens, JJ H and Gispen, WH, Depolarization-induced phosphorylation of the protein kınase C substrate B-50 (GAP-43) in rat cortical synaptosomes, J Neurochem, 54 (1990) 1645-1652

11 Dekker, L V, De Graan, P N E , Pınappel, P, Oestreıcher, A B and Gispen, WH, Noradrenalıne release from streptolysin $O$ permeated rat cortical synaptosomes effects of calcium, phorbol esters, protein kinase inhibitors, and antibodies to the neuronspecific protein kınase C substrate B-50 (GAP-43), J Neurochem. 56 (1991) 1146-1153

12 Dokas, L A, Pisano, M R, Schrama, L H, Zwiers, H and Gispen, W H , Dephosphorylation of B-50 in synaptic plasma membranes, Brain Res Bull, 24 (1990) 321-329

13 Dougherty, G G and Ellınwood, E H . Amphetamıne behavioral toxicity rotational behavior after chronic intrastriatal infusion, Btol Psychiat, 16 (1981) 479-488

14 Dunkley, P R, Jarvie, P E, Heath, J W, Kıdd, G J and Rostas, $\mathrm{J} \mathrm{A}$, A rapid method for isolation of synaptosomes on Percoll gradients, Brain Res, 372 (1986) 115-129

15 Dunkley, P R, Jarvie, PE and Rostas, J A, Distribution of calmodulın- and cyclıc AMP-stımulated protenn kınases in synaptosomes. $J$ Neurochem, 51 (1988) 57-68

16 Fischer, J F and Cho, A K, Chemical release of dopamıne from striatal homogenates evidence for an exchange diffusion model, $J$ Pharmacol Exp Ther, 192 (1979) 642-653

17 Gianottı, C, Nunzı, MG, Gispen, WH and Corradettı, R, Phosphorylation of the presynaptic protein B-50 (GAP-43) is increased durıng electrically induced long-term potentiation, Neuron, 8 (1992) 843-848

18 Gispen, W H, Nielander, H B, De Graan, P N E, Oestreicher, A B , Schrama, L H and Schotman, P, Role of the growth-assocrated protein B-50/GAP-43 in neuronal plasticity, Mol Neurobiol, 5 (1991) 61-85

19 Gnegy, M E. Hewlett, G H K, Yee, S L and Welsh, M J , Alterations in calmodulin content and localization in areas of rat brain after repeated intermittent amphetamıne, Brain Res, 562 (1991) $6-12$

20 Han, Y, Wang, W, Schlender, K K, Ganjeizadeh, M and Dokas, L A, Protein phosphatases 1 and $2 \mathrm{~A}$ dephosphorylate B-50 in presynaptic plasma membranes from rat brain $J$ Neurochem, 59 (1992) 364-374

21 Hemmıngs, H C Jr, Naırn, A C McGuınness, T L, Huganır, 
RL and Greengard, $P$, Role of protein phosphorylation in neuronal signal transduction, FASEB J , 3 (1989) 1583-1592

22 Janowsky, D S and Risch, C Amphetamine psychosis and psychotic symptoms, Psychopharmacology 65 (1979) 73-77

23 Kalivas PW and Weber, B Amphetamine injection into the ventral mesencephalon sensitizes rats to peripheral amphetamıne and cocaine, $J$ Pharmacol Exp Ther, 245 (1988) 1095-1102

24 Kandel, E R and Schwartz, J H, Molecular biology of learning modulation of transmitter release, Sctence, 218 (1982) 433-443

25 Karler, R Chaudhry, I A Calder, L D and Turkanıs S A Amphetamıne behavioral sensitization and the excitatory amino dcids, Brain Res 537 (1990) 76-82

26 Kennedy M B Regulation of synaptic transmission in the central nervous system long-term potentiation, Cell 59 (1989) 777 787

27 Kitano, T, Go, M Kıkkawd U and Nishızukd Y, Assav and purification of protein kinase C Meth Enzvmol, 124 (1986) 349-352

28 Koltd, M G Shreve, P and Uretsky N J, Effect of pretredtment with amphetamine on the interaction between amphetamine and dopamine neurons in the nucleus accumbens, Neuropharmacologv 28 (1989) 9-14

29 Kuczenski, R and Segal D S Psychomotor stımulant-induced sensitization behavioral and neurochemical correlates In P W Kalivas and CD Barnes (Eds), Sensitization in the Nertous Svitem, Teltord, Caldwell, NJ, 1988 pp 175-205

30 Liu Y and Storm D R Dephosphorylation of neuromodulin bi calcineurin, J Brol Chem 264 (1989) 12800-12804

31 Liu Y C and Storm, D R, Regulation of free calmodulın levels by neuromodulin neuron growth and regeneration Trends Pharmacol Scl 11 (1990) 107-111

32 Lovinger, DM Colley, PA Akers, RF Nelson, R B and Routtenberg, A, Direct relation of long-term synaptic potentiation to phosphorylation of membrant protein Fl a substrate for membrane protein kınase C, Brain Res, 399 (1986) 205-211

33 Lynch, $G$ and Baudry, M, Bran spectrin, calpain and long-term changes in synaptic efficacy Brain Res Bull, 18 (1987) 809-815

34 Mangels L A and Gnegy ME, Muscarinic receptor-medidted translocation of calmodulın in SK-N-SH human neuroblastoma cells, Mol Pharmacol 37 (1990) 820-826

35 Meirı, K F and Burdick, D, Nerve growth factor stımulation of GAP-43 phosphorylation in intact isolated growth cones $J$ Neurosel $11(1991) 3155-3164$

36 Meıri, KF and Gordon-Weeks, P R GAP-43 in growth cones in associated with areas of membrane that dre tightlv bound io substrate and is a component of a membrane skeleton subcellular traction $J$ Neuroset $10(1990) 256-266$

37 Nelson, R B Linden, D J and Routtenberg A Phosphoproteins localized to presynaptic terminal linked to persistence of long-term potentidtion (LTP) quantitative analysis of two-dımensional gels, Brain Res 497 (1989) 30-42

38 Neve, R L Ivıns, K J , B cnowitz L I Durıng, M J and Geller A I Molecular analysis of the tunction of the neuronal growthassociated protein GAP-43 by genetic intervention Mol Neurohol 5 (1991) 131-141

39 Patrick S L Thompson T L, Walker JM and Patrick R L Concomitant stnsitization of amphetamıne-induced behavioral stimulation and in vivo dopamine reledse from rat caudate nucleus, Brain Res 538 (1991) 343-346

40 Paulson PE Camp D M and Robinson. TE, The time course of transient behavioral depression and persistent behavioral senstization in relation to regiondl brain monoamıne concentrations during amphetamine withdrawal in rats, Psvchopharmacolog 103 (1991) 480-492

4 Popov N Schulzeck S Nuss, D, Vopel A-U, Jendrnv (, Struy, $\mathrm{H}$ and Matthies, $\mathrm{H}$, Alterations in calmodulin content of rat bran areas after chronic application of haloperidol and amphetamine, Biomed Blochim Acta 47 (1988) $435-441$

42 Popov, NS Reymann KG Schulzeck K Schulzech S and Matthies, $\mathrm{H}$ Alterations in calmodulin content in fractions of $\mathrm{rat}$ hippocampal slices during tetanic-and calcium-induced long-term potentiation Bram Res Bull 21 (1988) 201-206

43 Roberts-Lewis J M Welsh, M J and Gnegy, ME Chronic amphetamine treatment increases stridal calmodulın in rats Bratn Res 384 (1986) 383-386

44 Robinson, P J , The role of protein kinase $\mathrm{C}$ and its neuronal substrates dephosphin, B-50 and MARCKS in neurotransmıtter release, Mol Neurobiol, 5 (1991) 87-130

45 Robinson, T E Behavioral stnsitization characterization of enduring changes in rotational behavior produced bv intermittent injections of amphetamine in male and female rats Psychopharmacologr 84 (1984) 466-475

46 Robinson, TE, The neurobiology of amphetamine psychosis Evidence from studies with an animal model In $T$ Nakdzawd (Ed), Taniguchi Svmposia on Bran Sctences, l'ol 14, Biological Bases of Schizophrenc Disorders Japan Scientific Societies Press Tokyo, 1991, pp 185-201

47 Robinson TE and Becker J B Behavioral sensitization is decompanied by an enhancement in amphetamine-stimulated dopamine release from stridal tissue in vitro Eur $J$ Pharmacol 85 (1982) 253-254

48 Robinson, TE and Becker J B Endurıng changes in braın and behdvior produced by chronic amphetamine administration a review and evaluation of animal model of amphetamine psychosis Brain Res Ret 11 (1986) 157-198

49 Rose S PR How chick make memornes The cellular cascade trom c-fos to dendritic remodelling, Trends Neuroset 14 (1991) 390-397

50 Roseboom PH Hewltt GHK and Gnegy ME Repedted Amphetamine Administration diters the interaction between D1stimulated adenylyl cyclase activity and calmodulin in rat stridtum J Pharmacol Exp Ther 255 (1990) 197-203

51 Sato, $M$ Acute exacerbation of methamphetamıne psvchoss and lasting dopaminergic supersensitivity - d clinical survey, $P_{\$ 1-}$ chopharmacol Bull, 22 (1986) 75-756

52 Sato M A lasting vulncrability to psychosis in patients with previous methamphetamıne psvchosis Ann NY Acad Sol 654 (1992) $1601-170$

53 Skene JHP Axonal growth-associdted protens Annti $R_{t l}$ Neuroset 12 (1989) 127-156

54 Snyder SH Amphetamıne psychosis a model schizophrenla mediated by catecholdmines Am J Psychatr, 130 (1973) 61-67

55 Spencer S A Schuh SM Liu W-S and Willard, M B, GAP43 a protein associdted with dxon growth is phosphorylated at three sites in cultured neuroms and rat brain $J$ Biol Chem 267 (1992) 9059-9064

56 Stewart J and Vezina $P$ Micromjections of S( H-23390 into the ventral tegmental area and substantia nigra pars reticulata dttenuate the development of sensitization to the locomotor activating effects of svstemic amphetamine Brain Res 495 (1989) 4(31-406

57 Uranovd, N A Klintzovd A J Istomın V V, Haselhorst, U and Schenk, $\mathbf{H}$ The eftects of amphetamine on svnaptic plasticity in rat s medial pretrontal cortex $J$ Hirnforsch 30 (1989) 45-50)

58 Yamada $\mathrm{S}$ Kojıma $\mathrm{H}$, Yokoo $\mathrm{H}$ Tsutsumı, T Takamuki $\mathrm{K}$ Anraku, S Nishi, $S$ and Inanagd $K$ Enhancement of dopamine release trom striatal slices of rats that were subchronically treated with metamphetamine Btol Puchat 24 (1988) 399-408

59 Yasuda, I Kishımoto, A Tanaka, S Tominagd M Sakurdı A and Nishizukd Y A synthetic peptide substrate for selective dssdy of proten kindse C Blochem Biophws Re's Commun 166 (1990) 1220-1227

60 Yovell $\mathrm{Y}$ and Abrams T W Ttmporal asymmetry in activation of Aplysea adenylyl cyclase by calcium and transmitter mav cxplan tempordl requirements of conditioning Proc Natl Acad SA USA 89 (1992) 6526-6530)

6) Zaczek R Culp S Goldberg, H McCann D J and De Souzd

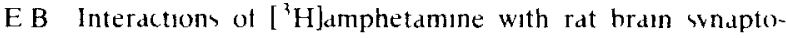
somes I baturable sequastration $J$ Pharmacol Exp Ther 257 $(1991) 82(1+829$ 